\title{
Feedstock diversification for biodiesel production in Brazil: Using the Policy Analysis Matrix (PAM) to evaluate the impact of the PNPB and the economic competitiveness of alternative oilseeds
}

\author{
Camila Elisa dos Santos Alves ${ }^{\mathrm{a}}$, Luiz Clovis Belarmino ${ }^{\mathrm{b}}$, Antonio Domingos Padula ${ }^{\mathrm{c}, *}$ \\ a Universidade Federal do Rio Grande do Sul - UFRGS, Programa de Pós-Graduação em Agronegócios - PPG-Agronegócios, Av. Bento Gonçalves 7712 - \\ Prédio da Agronomia - 1..$^{\circ}$ Andar, CEP.: 91540-000 Porto Alegre, RS, Brasil \\ b Empresa Brasileira de Pesquisa Agropecuária (Embrapa), Rodovia BR-392, Km 78, $9^{\circ}$ Distrito, Monte Bonito, Caixa Postal 403, CEP: $96010-971$ Pelotas, \\ RS, Brasil \\ ${ }^{c}$ Universidade Federal do Rio Grande do Sul - UFRGS, Escola de Administração - EA, Programa de Pós-Graduação em Administração -PPGA, Programa \\ de Pós-Graduação em Agronegócios - PPG-Agronegócios, Rua Washington Luis, 855, CEP 90010-460 Porto Alegre, RS, Brasil
}

\section{A R T I C L E I N F O}

Keywords:

Biodiesel

Feedstock diversification

Green energy economy, green industrial policy

Policy analysis matrix (PAM)

\begin{abstract}
A B S T R A C T
While biodiesel feedstock diversification is a main objective of the Brazilian National Program for the Production and Use of Biodiesel (PNPB in Portuguese), its achievement has remained elusive and biodiesel is predominantly produced from soybean (75\%). This research uses the Policy Analysis Matrix (PAM) approach to evaluate the PNPB effects and compare the economic efficiency and the competitiveness of biodiesel from three oilseeds: soybean, rapeseed and sunflower. In contrast to papers that present results of experimental biodiesel production initiatives, this paper explores the case of "representative" production chains (best available technology and management practices). The findings indicate that biodiesel production is competitive from the three oilseeds, but the profitability of biodiesel from the soybean is notably higher. The tax breaks and subsidies provided by the PNPB have a positive impact on the profitability of biodiesel production chains $(7.43 \%$ for soybean, $3.88 \%$ for rapeseed, $5.53 \%$ for sunflower). These results are encouraging and suggest two actions: i) to review the incentive policies (tax reduction) and payments to farmers of the different crops (pay for oil content instead of crop yield); and ii) to invest in organizational and managerial approaches in the alternative oilseed agricultural systems to improve their technical and economic efficiency.
\end{abstract}

\section{Introduction}

The search for energy matrices with a higher content of renewable energy has stimulated efforts in various countries to produce and use ethanol and biodiesel to substitute or to complement gasoline and diesel (Fagundes et al., 2016; White et al., 2013). In overviewing the policies that have encouraged the biofuels production and consumption across the world, Drabik et al. (2014), Sorda et al. (2010) and Stattman et al. (2013) identified that biofuels has expanded strongly in recent decades as a result of public policies designed to incentive diversification of the energy matrix.

The role of renewable energy is expanding beyond the energy matrix. In the recent decades the "Green Economy" (GE) paradigm has emerged, which aims to reconcile environmental and socio-economic development (Pahle et al., 2016). Renewable energy is a critical element within the GE (Besi and McKormic, 2015; Shah and Niles,
2016). The transition to a GE is a challenge and various countries are designing and implementing policies and initiatives to move to a GE. Germany is championing the transition to a GE (Ringel et al., 2016). France is changing the forest policy regime to prioritize wood as a biomass resource (Sergent, 2014). Los Angeles (USA) has a policy agenda to improve its green energy capacity (Monstadt and Wolff, 2015). The Caribbean countries are encouraging the production and consumption of bioenergy to promote socio-economic development and energy security (Shah and Niles, 2016). Colombia is implementing public policies to encourage the production of biodiesel from palm oil to create jobs and improve farmers' income (Castiblanco et al., 2015; Rincón et al., 2015). African countries are designing and implementing bioenergy policies to promote socio-economic development (Mulugetta, 2009). Ethiopia is revising its energy policy and investing in ethanol and biodiesel production to create jobs and reduce fossil fuel imports (Gebreegziabher et al., 2013). The European Union (EU) is

\footnotetext{
* Corresponding author.

E-mail addresses: camilaelisaalves@gmail.com (C.E. dos Santos Alves), belarminster@gmail.com (L.C. Belarmino), adpadula@ea.ufrgs.br (A.D. Padula).
} 
learning from the British experience of electricity market reform to design policies to reduce subsidies in the EU electricity systems and encourage the expansion of renewable energy (Newbery, 2016).

Mundaca et al. (2016) proposed an even more extended definition for what they are defining as a transition to a "Green Energy Economy" (GEE). They characterize GEE as "the scientific and policy subject area that focuses on how the expansion of resource-efficient and low-carbon energy technology systems, markets and services can bring together economic, environmental, social and security aspects. A key focus of a GEE is policies and strategies that are designed to foster the rapid transition towards sustainable energy economy systems".

Governmental intervention in the economic system to stimulate the development of a specific sector (vertical policy) or industries as a whole (horizontal policy) is known as Industrial Policy (Lazzarini, 2015). The debate supporting government intervention in the market goes back to the 19th century, when the corpus of the neoclassical economy theory was constructed (Williams, 2010). The literature on industrial policy argues that government intervention can help overcome market failures and provide incentives for further industrial development (Farla, 2015; Rodrik, 2009). Analytical frameworks provided by the neoclassical Industrial Policy (quantitative analysis of large datasets (Kiyota and Okazaki, 2016)) are frequently adopted to assess the effects and impacts of public policies intended to encourage the development of GE (Brown et al., 2014; Rodrik, 2014). The traditional industrial policy approach has been used to evaluate effects on job creation of the Clean Development Mechanism (CDM) in China (Wang et al., 2013), the volatility in the electricity market provoked by Gemany's green energy policy (Auer, 2016), the implications of the EU green energy policy on financial performance of crop production and water management (Vochozka and Marousková, 2017), the impacts of green credit on energy-intensive industries in China (Liu et al., 2015), the competitiveness of wind and solar PV energy systems in Germany (Pegels and Lütkenhorst, 2014), and the effect of renewable energy consumption on economic growth (Bhattacharya et al., 2016).

In the transition to a GEE, the challenge for policy-makers is to ensure that investments in green energy technology and production systems take place in a sustainable way (Rodrik, 2014; Schmitz et al., 2013). Implementing stimulus packages targeted at advancing the transition to a GEE is complex, risky, uncertain and knowledge fragmented (Mundaca . et al., 2016). Rodrik (2014) argues that policy designed to encourage the transition to GEE is a specific kind of Industrial Policy and needs an appropriate institutional framework. To overcome the limits of traditional industrial policy he proposed an approach to designing and implementing green energy policies that has been called "Green Industrial Policy" (GIP). GIP is a framework of institutions and public policies (subsidies, tax reductions, regulations, incentives, etc.) designed to support and foster investments in technologies and production systems that economize on exhaustible resources and emit fewer greenhouse gases (Besi and McKormic, 2015; Pegels and Lütkenhorst, 2014; Rodrik, 2014). GIP deals with the novelty, experimental nature and risks entailed in the technological and entrepreneurial process involved in the transition to a green economy (Mjimba, 2015).

In Brazil, in December 2004 the federal government created the National Program for Biodiesel Production and Use (PNPB in Portuguese), which established the regulatory framework through which biodiesel has been incorporated into the Brazilian energy matrix (Padula et al., 2012; Rathmann et al., 2010). The program's main guidelines are to: (i) implement a sustainable program, promoting social inclusion; (ii) guarantee competitive prices, quality and supply; (iii) produce biodiesel from various oilseeds, strengthening the regional potentialities for the production of the raw material (MDA, 2015).

The PNPB was designed and implemented to establish a biodiesel "industry" in Brazil involving different agents, links and sectors in the production and consumption of biodiesel. Since its launch, the PNPB has already produced a volume of 15.5 billion liters of biodiesel (ANP,
2015) and reduced the cost of diesel oil imports by US $\$ 5.3$ billion (MME, 2015). In 2015, Brazil produced 3.94 billion liters of biodiesel, and is the 2nd largest producer, surpassed only by the USA that produced 4.80 billion liters. Germany, the 3rd largest producer, produced 2.80 billion liters (USDA, 2015). Brazil blends $7 \%$ of biodiesel into fossil diesel (B7) from 2014 onwards.

The PNPB establishes the rules, standards, plans, programs, tax incentives and subsidies for biodiesel production and consumption. Tax incentives and subsidies granted by PNPB seek to favor socioeconomic aspects such as the inclusion of family farming, the diversification of raw materials (castor bean, palm, sunflower, rapeseed and jatropha, among others) and the production of biodiesel from oil produced in the poorest regions of the country (Northeast and the North). In Brazil, in 2014, there were 73,479 families involved in the production of biomass for biodiesel. Those families traded US \$ 1.1 billion in raw materials with companies holding the Social Fuel Stamp in 2015 (MDA, 2015), which is a certificate that ensures the raw material for biodiesel production originates from family farming.

Although the PNPB has created tax incentives and subsidies to encourage the diversification of oilseed production, they seem to have had little impact on biodiesel feedstock diversification (Bergmann et al., 2013; Rathmann et al., 2012; Zonin et al., 2014). Soybean oil was used as the raw material for approximately $75 \%$ of the biodiesel produced in Brazil in 2015 (ANP, 2015; ABIOVE, 2016), as illustrated below, in Fig. 1.

The issue of feedstock diversification for producing biodiesel has been the subject of case studies in several Brazilian regions. Santos and Rathmann (2009) identified the production and organizational challenges involved in producing biodiesel from castor bean in the state of Piauí. Projects to produce biodiesel from castor bean in the semi-arid region are facing huge problems to celebrate contracts with family farms and are not reaching their objectives (César and Batalha, 2010). The lack of horizontal organization among family farms is the primary obstacle to developing biodiesel from castor bean in the states of Paraíba (Souto and Sicsú, 2011) and Minas Gerais (César and Batalha, 2011; Watanabe and Zylbersztajn, 2012). Vaz et al. (2010) identified that to be competitive in relation to soybean biodiesel, castor bean farming needs to improve its productivity in the Northern region. Although biodiesel from palm oil is encouraged by the PNPB, the volume of palm oil production in the North and Northern regions has not achieved economic scale (César et al., 2013; Takahashi and Ortega, 2010). Rathmann and Padula (2011), Vaccaro et al., 2010 and Zonin et al. (2014) identified why soybean is the first choice feedstock for biodiesel processing plants in the state of Rio Grande do Sul. Dal Belo Leite et al. (2015) assessed the socioeconomic and environmental benefits of producing alternative crops on family farms in the state of Minas Gerais and found that the scope for alternative sustainable biodiesel crops is limited in that state.

Similarly, the objective of expanding the production of alternative oilseeds and biodiesel in the poorest regions of the country (Fig. 2), such as the North (2\%) and Northeast (8\%), has not been achieved (Rathmann and Padula, 2011; Cesar et al., 2013; Dal Belo Leite et al.,

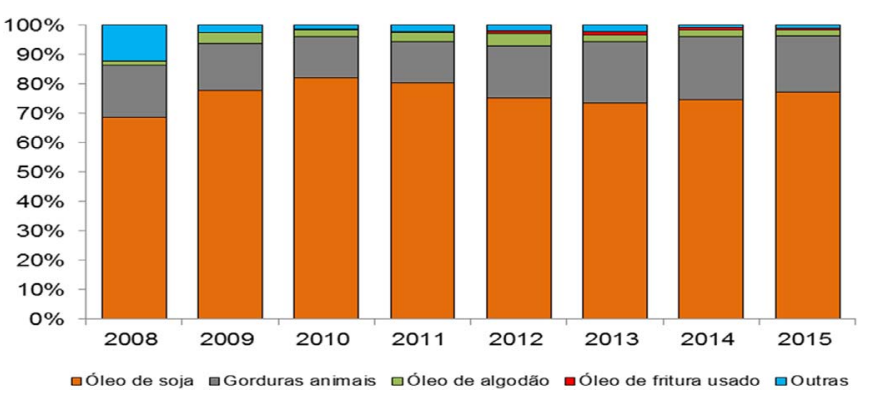

Fig. 1. Biodiesel Production by feedstock 2008-2015(\%). Source: Based on data from the ANP (2016) and ABIOVE (2016). 


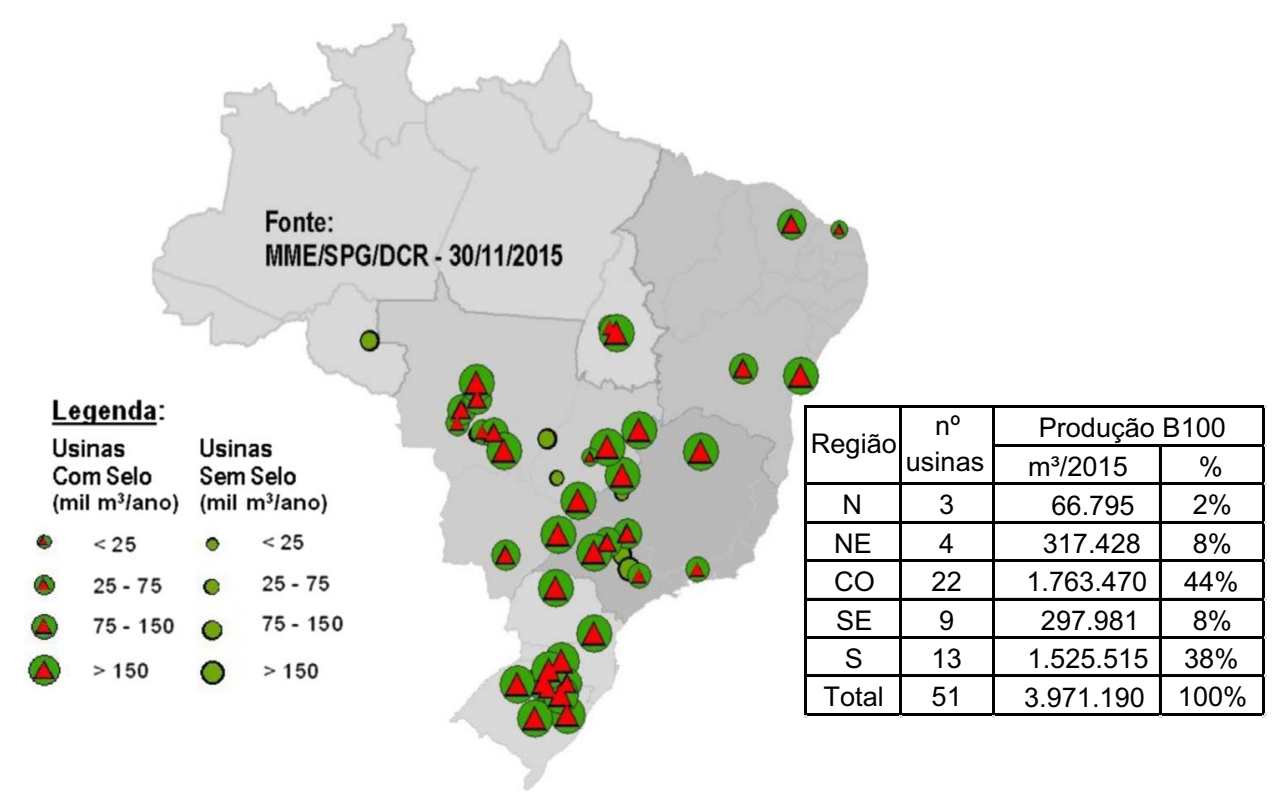

Fig. 2. Biodiesel production by region in Brazil in 2015. Source: ANP (2016).

2013). The South (38\%) and Midwest (44\%) regions, being the major soybean producers, are the leading biodiesel producers (ANP, 2016).

The goal of producing biodiesel from castor bean (Watanabe and Zylbersztajn, 2012), sunflower, rapeseed and palm (Cesar and Batalha, 2011) in different Brazilian regions seems far from being achieved due to low production and productivity, the predominance of production on small family farms, disorganization and poor consolidation of these production chains (Dal Belo Leite et al., 2013, 2014; Florin et al., 2013).

The exploratory studies listed above demonstrate that the alternative oilseed production systems for biodiesel production are still rudimentary, experimental and surrounded by uncertainty in the various Brazilian regions. The knowledge on the implementation of the PNPB is being constructed in a fragmented way from case studies describing initiatives involving castor bean, sunflower, and rapeseed and palm. The PNPB has multiple objectives and its implementation has revealed the elements that Rodrik (2014) characterizes as a "Green Industrial Policy”, namely: novelty, an experimental nature, risks and uncertainties. Considering its evolution in terms of renewable energy production and consumption in recent decades, with the share of renewable in the Brazilian energy matrix reaching 41.2\% in 2016 (Agenciabrasil, 2016), Brazil can also be seen as being in the midst of a transition towards what Mundaca et al. (2016) and Pahle et al. (2016) have characterized as "Green Energy Economy".

When dealing with the transition towards a GEE, Pahle et al. (2016) and Ürge-Vorsatz et al. (2016) argue that policy-makers need analytical frameworks that are better suited to assess the multiple effects and impacts of GEE policies. Within the literature on the emerging Brazilian biodiesel industry it prevails fragmented knowledge and data produced by exploratory studies (listed above) into experimental agricultural systems for producing alternative crops (castor bean, palm, sunflower, rapeseed). Considering the lack of exhaustive technical and economic data on those production systems it is unfeasible to use a traditional empirical quantitative approach to assess the competitiveness of such alternative crops in the production of biodiesel. It seems opportune and appropriate to identify production systems that are technological advanced and organizationally well managed to be used as benchmarks to assess and quantify the effectiveness of the PNPB's Green Industrial Policy (subsidies, tax reduction, incentives, etc.), and compare the economic viability and the competitiveness of the whole production chain of biodiesel from different oilseeds such as soybean, rapeseed, sunflower, castor and palm, for example.
The state of Rio Grande do Sul is Brazil's largest biodiesel producer (30\% of the total production), largest rapeseed producer and the largest producer of biodiesel from sunflower oil (Colussi, 2014). In contrast to the states in the North and Northern regions, the agricultural and processing systems in Rio Grande do Sul have a technological and managerial leading position in the biodiesel business in Brazil (Silva and Freitas, 2008; Viegas, 2014; Savi and Kochhan, 2016). Therefore, it seems pertinent to explore the case of biodiesel production in Rio Grande do Sul in order to assess the impact of the PNPB incentives, the competitiveness and the efficiency of alternative biodiesel feedstock supply chains in a benchmark production chain.

The economic viability and competitiveness of production chains are related to productivity, technology adaptation, the costs and conditions of acquiring inputs, the degree of product differentiation and market share (Ferraz et al., 1996), as well as factors external to the production chains, such as government intervention in economic activity (Kennedy et al., 1998; Williams, 2010). Pahle et al. (2016) and Ürge-Vorsatz et al. (2016) suggest that to deal with green energy (GE) policies, policy-makers need appropriate analytical frameworks to evaluate the multiple effects and impacts of this kind of policies. Assessing competiveness and the PNPB's green industrial policy impacts requires a detailed structure to collect data about inputs, outputs, production factors, national and international prices, costs, tax, subsidies, revenues and profits in each of the links along the biodiesel supply chain (inputs, agriculture, processing plants, transportation and distribution). To address this kind of issue, a group of researchers from The Cornell University (Monke and Pearson, 1989) proposed the Policy Analysis Matrix (PAM) approach.

The PAM provides indicators of the impacts of public policies and economic performance elements, since it: identifies the profitability of the production chain links and the chain as a whole, before and after investment; evaluates the cost savings after making investments; and identifies the most efficient and the weakest links in a production chain (Monke and Pearson, 1989; Torres et al., 2013). The PAM also produces consistent indicators for assessing competitiveness, comparative advantage and market failures brought about by agricultural policies that can distort the domestic and international markets for agro-industrial products (Liefert and Westcott, 2015).

The PAM approach has gained acceptance both among scholars, for the study of competitiveness, as well as among policy-makers, for the formulation and implementation of agro-industrial policies (Vieira, 1996). Nelson and Panggabean (1991) used the PAM to analyze the 
effects of Indonesia's policy regarding sugar production. Pearson et al. (2003) explored multi-cases studies to evaluate agricultural policies in Indonisia. The PAM was used by Ugochukwu and Ezedinma (2011) to assess the impacts of intensifying rice production systems in Southeastern Nigeria. Souza et al. (2017) combined primary data from representative establishments and secondary data to make economic and accounting evaluation of the rice production chains in Rio Grande do Sul (Brazil) and Uruguay. FAO (2007) also recommends the PAM approach to assess the effect of agricultural policies and the competitiveness of agricultural systems worldwide.

The PAM approach explores real "representative" production systems to collect detailed real economic and production data (Monke and Pearson, 1989). The "representative" establishment is that which uses the best available technology and adopts appropriate management principles, and is thus better than the other production and marketing agents, i.e. it constitutes a reference production system and benchmark for market efficiency in the studied production chains (Lopes et al., 2012). PAM can also use exhaustive secondary data to compare and validate the primary data collected in the representative production system. Therefore, researchers should make full use of available secondary data and collect good quality primary data to seek trends and confirmation (Pearson et al., 2003). Considering the research issue raised in this paper and the characteristics of the PAM presented above, we argue that the PAM approach is a well-suited analytical framework to assess the PNPB's green industrial policy impacts and the competiveness of the alternative crops (soybean, sunflower and rapeseed) in the production of biodiesel.

In contrast to the papers previously cited in this introduction, which studied experimental initiatives involving the use of alternative oilseeds in biodiesel production, this paper explores the case of a wellestablished production chain in Rio Grande do Sul, which is the leading biodiesel producing state in Brazil (Colussi, 2014; Savi and Kochhan, 2016; Viegas, 2014). In the production chains where primary data were collected, the agricultural production of oilseeds and the biodiesel plants are technology-intensive and can be considered benchmarks in the biodiesel industry. The economic and production indicators identified in these "representative" production chains could be taken into account when considering any revision of the PNPB's incentive policies and the investment decisions regarding the production systems and alternative oilseed chains (rapeseed, sunflower, castor bean, palm, jatropha) with a view to diversify the raw materials for biodiesel production in Brazil.

Following the introduction, this paper contains the conceptual framework used to construct the analytical research structure based on the Policy Analysis Matrix and the biodiesel chain in Brazil (Section 2), the research methodology (Section 3), the results presentation and discussion (Section 4), and the conclusions and conceptual, managerial and public policy implications that can be drawn from the results of the study (Section 5).

\section{Theoretical basis}

This section introduces the main conceptual elements that support the analytical framework adopted in this research. It begins by discussing concepts related to competitiveness and economic efficiency, and provides a concise presentation of the approach proposed by the Policy Analysis Matrix (PAM). Then, it deals with public-policy incentives, regulations and guidelines established by the National Program for Biodiesel Production and Use (PNPB in Portuguese). Finally, we present the biodiesel production chain.

\subsection{Competitiveness, economic efficiency and the Policy Analysis Matrix (PAM)}

The term competitiveness is approached from different perspectives. The diversity of definitions comes in large part from the wide range of areas of knowledge that have appropriated the term when conducting research and performing analysis of economic sectors (César and Batalha, 2010). Ferraz et al. (1996) address competitiveness through two lenses. The first defines competitiveness in terms of performance expressed in market share and the second as efficiency, based on productivity. For Porter (1985), the fundamental basis of above average performance in the long run is the competitive advantage: lower costs and/or differentiation of its products. Latruffe (2010) considers productivity and efficiency to be indicators or measures of competitiveness. A general definition of productivity is the ability to use the production factors (inputs) efficiently, so as to produce maximum outputs with the minimum of inputs. While efficiency indicates the degree to which the technology or inputs are used in the best possible way.

The efficiency and competitiveness of agro-industrial chains are not merely effects of the allocative efficiency, which is the ability to use inputs in optimal proportions given their prices, but also of taxation policies in domestic market and measures arising from national and international trade policies (Lopes et al., 2012). Agro-industrial competitiveness is a result not only of the individual behavior of companies but also the own production system, that is, the entire agribusiness chain (César and Batalha, 2010).

As shown above, the analysis of competitiveness and economic efficiency should go beyond the costs and profitability approach, that is, such an analysis should also take into account government intervention policies such as currency exchange rates, interest, social contributions, subsidies, taxes and other duties (Lopes et al., 2012). Among the different approaches adopted when studying competitiveness in economic sectors influenced by public policies, the Policy Analysis Matrix (PAM), proposed in the late 1980s by Monke and Pearson (1989), has often been used in agro-industrial production systems. The PAM method uses a logical framework designed for the analysis of the impact of the public policies that affect the economic results of production activities in developing countries. The PAM is an approach to the analysis of two accounting identities: i) private profit, defining profitability as the difference between revenues and costs; and, ii) social profit, which evaluates the effects of divergences (policy distortions and market failures) as a result of the difference between the parameters observed in the domestic market (private prices) and indices and indicators that would exist if the divergences were removed (social prices) (Monke and Pearson, 1989).

The method proposed in the PAM allows an integrated and dynamic view of the production process. According to Monke and Pearson (1989), three issues can be investigated with the PAM approach: (i) the impact of public policies on the competitiveness of commodity systems; (ii) the influence of the investment policy on economic efficiency and comparative advantage; and (iii) the effects of agricultural research policy on the processes of technological change.

In the PAM, profitability is measured horizontally through the matrix columns, and the profit is shown in the last column on the right (Fig. 3), which is derived by subtracting the costs of the intermediate inputs and domestic factors indicated in the central column from the revenue indicated in the left column. Tradable inputs include fertilizers, pesticides, purchased seeds, compound animal feed, electricity, transportation and fuel. This process of disaggregating goods or domestic factors from intermediate goods and services separates intermediate costs into different categories to facilitate the calculation of the effects of policies and prices on each component of costs (fixed, labor, variable inputs and taxes) (Monke and Pearson, 1989).

Fig. 4 presents the elements of cost, revenues and profits in the four links in a biodiesel supply chain. When calculating the invested capital, labor and input costs and product prices (national), the elements relative to subsidies, fees, taxes, social charges, and exchange variation should be considered to obtain the private costs and revenues. For the calculation of the supply chain's social indicators, taxes, subsidies and social charges should be deducted, and international prices should be 


\begin{tabular}{|l|c|c|c|c|}
\hline \multirow{2}{*}{} & & \multicolumn{2}{|c|}{ Costs } & \multirow{2}{*}{ Profit } \\
\cline { 3 - 4 } & Revenue & Tradable Inputs & Domestic Factors & D (1) \\
\hline Private Price & A & B & C & H (2) \\
\hline Social Price & E & F & G & L (6) \\
\hline Divergence & I (3) & J $(4)$ & K $(5)$ & \\
\hline
\end{tabular}

(1) Private Profits $(D=A-B-C)$

(2) Social Profits $(\mathrm{H}=\mathrm{E}-\mathrm{F}-\mathrm{G})$

(3) Output Transfers ( $I=A-E)$

(4) Input Transfers $(\mathrm{J}=\mathrm{B}-\mathrm{F})$

(5) Factor Transfers $(\mathrm{K}=\mathrm{C}-\mathrm{G})$

(6) Net Transfers $(\mathrm{L}=\mathrm{D}-\mathrm{H}$ or $\mathrm{L}=\mathrm{I}-\mathrm{J}-\mathrm{K})$

Fig. 3. The accounting structure of the Policy Analysis Matrix (PAM). Source: Adapted from Monke and Pearson (1989) and Lopes et al. (2012).

used to show the effective social contribution of the supply chain, as proposed by Monke and Pearson (1989, pp. 10-20).

In the Policy Analysis Matrix, profit occurs in two spheres: private and social. The private indicators provided by the PAM refer to the internal market, while, the social indicators refer to the international market values. Private profit $(\mathrm{D}=\mathrm{A}-\mathrm{B}-\mathrm{C})$ indicates competitiveness based on real market costs and prices, which permits comparisons between different systems producing the same product (Torres et al., 2013). If Private profits are negative ( $\mathrm{D}<0$ ), producers will earn a subnormal rate of return; if private profits are positive $(\mathrm{D}>0)$, producers will earn an above-normal rate of return. Therefore, normal profits mean D = 0 (Monke and Pearson, 1989).

In turn, Social profit $(\mathrm{H}=\mathrm{E}-\mathrm{F}-\mathrm{G})$ measures the efficiency of the agricultural system or its comparative advantage. In the PAM method, the concept of comparative advantage is used as a measure of the social or economic profitability, that is, it represents the level of efficiency in the allocation of national productive resources. When negative $(\mathrm{H}<$ 0 ), social profit indicates the system is considered not economically viable in the international context (Torres et al., 2013). With negative social profits, the system cannot survive without government assistance. On the other hand, $\mathrm{H}>0$ indicates economic efficiency in production chains. Efficient results are achieved when the resources in the studied economy are used in activities that create the highest levels of production and income (Monke and Pearson, 1989). Normal profit occurs if $\mathrm{H}=0$.

The Net transfer $(\mathrm{L}=\mathrm{D}-\mathrm{H}$ or $\mathrm{L}=\mathrm{I}-\mathrm{J}-\mathrm{K})$ is the indicator used to measure and reveal the distorting effects of governmental interventionist policies (Monke and Pearson, 1989). The monetary value of ' $L$ ' represents how much has been transferred from or to the analyzed chain. The net transfer (L) is the sum of the effect of all the policies considered on the product prices, the marketable input costs, and on the production factors costs (Torres et al., 2013). L > 0 means that through public policies the government transferred a certain monetary value to the producer. $\mathrm{L}<0$ denotes that through public policies the government transferred a certain monetary value from the producer to other economic sectors. For Monke and Pearson (1989), efficient systems make profits without any government help or subsidies. Subsidy policies allow inefficient systems to survive over time.

The Policy Analysis Matrix provides other performance indicators and coefficients that allow the study of competitiveness and efficiency in supply chains, such as: Share of profits in the revenue (SPR = D/A),
Share of added value in the revenue $($ SAVR $=(A-B) / A)$, Share of the domestic factors for the added value $(\mathrm{SDFAV}=\mathrm{C} /(\mathrm{A}-\mathrm{B})$ ), Total productivity of the factors $(\mathrm{TPF}=\mathrm{A} /(\mathrm{B}+\mathrm{C}))$, Nominal protection coefficient of the product (NPCP $=\mathrm{A} / \mathrm{E})$, Nominal protection coefficient of the input (NPCI $=\mathrm{B} / \mathrm{F})$, Effective protection coefficient $(\mathrm{EPC}=(\mathrm{A}-$ B) $/($ E-F $)$ ), Profitability Coefficient $(\mathrm{CL}=\mathrm{D} / \mathrm{H})$, Vulnerability of the chain to policies $(\mathrm{VCP}=(\mathrm{H}-\mathrm{D}) / \mathrm{H})$, and Level of taxation in the chain $(\mathrm{LTC}=\mathrm{L} / \mathrm{H})$. To reduce repetition, a detailed description of these indicators and coefficients is presented in the results presentation and discussion (Section 4).

\subsection{Public policy and incentives for the biodiesel production in Brazil}

In this section, we present the main elements of the National Program for Biodiesel Production and Consumption (PNPB) and the tax incentives and subsidies that the program proposed for the production of biodiesel.

\subsubsection{The National Program for Biodiesel Production and Use (PNPB)}

The National Program for Biodiesel Production and Use (PNPB) regulates the Brazilian biodiesel production chain and incorporates economic, social and environmental aspects. In 2004 this program institutionalized the regulatory framework for the production, marketing and consumption of biodiesel in Brazil (MME, 2004). The production and marketing stimulus policies, the competitiveness drivers and the regulatory framework have had a significant impact on the structure, management and expansion of production and consumption of biodiesel in Brazil (Padula et al., 2012).

To ensure the PNPB fulfils the objectives of social inclusion and regional development, the Social Fuel Seal (SFS) was created. Biodiesel produced in processing plants that acquire feedstocks under production arrangements that include family farms receive the SFS. The basic requirements for obtaining the SFS are: (i) to be a legally constituted company; (ii) to have a biodiesel production project with at least the minimum criteria for social inclusion of family farmers and the minimum purchase of grains from those families (the minimum percentage of purchases of raw materials from family farmers are $30 \%$ for the Southeast, Northeast and Semi-Arid regions, $15 \%$ for the North and Mid-West regions, and, for the South region, 35\% in the 2012/2013 harvest and $40 \%$ in the 2013/14 harvest) and; (iii) the

\begin{tabular}{|l|l|l|l|l|}
\hline Supply Chain & $\begin{array}{l}\text { Link 1 } \\
\text { Agricultural } \\
\text { Production }\end{array}$ & $\begin{array}{l}\text { Link 2 } \\
\text { Transport from farms } \\
\text { to processing plant }\end{array}$ & $\begin{array}{l}\text { Link 3 } \\
\text { Oil and biodiesel } \\
\text { processing plant }\end{array}$ & $\begin{array}{l}\text { Link 4 } \\
\text { Transport from } \\
\text { processing plants to } \\
\text { distribution }\end{array}$ \\
\hline $\begin{array}{l}\text { Private and social } \\
\text { costs of links } \\
\text { (tradable inputs and } \\
\text { domestic factors) }\end{array}$ & $\begin{array}{l}\text { Invested capital, } \\
\text { labor, inputs }\end{array}$ & $\begin{array}{l}\text { Invested capital, } \\
\text { labor, intermediate } \\
\text { inputs }\end{array}$ & $\begin{array}{l}\text { Invested capital, } \\
\text { labor, intermediate } \\
\text { inputs }\end{array}$ & $\begin{array}{l}\text { Invested capital, } \\
\text { labor, intermediate } \\
\text { inputs }\end{array}$ \\
\hline Revenues & $\begin{array}{l}\text { Revenues from crops } \\
\text { selling }\end{array}$ & $\begin{array}{l}\text { Revenues from crop } \\
\text { transport to } \\
\text { processing plants }\end{array}$ & $\begin{array}{l}\text { Revenues from oil, } \\
\text { biodiesel and by- } \\
\text { products selling }\end{array}$ & $\begin{array}{l}\text { Revenues from } \\
\text { biodiesel transport to } \\
\text { distribution }\end{array}$ \\
\hline $\begin{array}{l}\text { Private and Social } \\
\text { Profits }\end{array}$ & Result & Result & Result & Result \\
\hline
\end{tabular}

Fig. 4. Elements of costs and revenues in a biodiesel supply chain. Source: adapted from Souza et al. (2017). 
existence of formal contracts providing for technical assistance and training plans for family farmers and/or agricultural cooperatives (MDA, 2012). Being awarded the right to use the SFS entitles the biodiesel producer to tax benefits, facilitated access to credit from the National Economic and Social Development Bank (BNDES) and the right to participate in biodiesel auctions held by the ANP - The National Petroleum, Natural Gas and Biofuel Agency (MDA, 2012).

\subsubsection{Tax incentives for biodiesel production in Brazil}

The impact of public policies (taxes, contributions, tariffs, duties, etc.) is a key element in agricultural production and marketing activities in developing countries. In Brazil, the National Tax Code establishes the general rules of tax law applicable to the Union, the States, the Federal District and the Municipalities, without prejudicing the respective complementary, supplementary or regulatory legislation (BRASIL, 1966).

With the creation and implementation of PNPB, a new tax framework for this biofuel was introduced, with the creation of differentiated tax mechanisms to encourage social inclusion in the production of biodiesel. The tax reductions related to biodiesel production factors vary according to the feedstock used and the region where the biofuel is produced, as shown in Fig. 5.

\subsection{Biodiesel production chain}

Biodiesel is a biofuel derived from renewable biomass, produced from vegetable oils or animal fats, for use in diesel engines or, according to regulations, to generate another type of energy that can partially or completely replace fossil fuels (Queiroz et al., 2012). This study deals with the production of biodiesel from vegetable oils. The biodiesel production cycle comprises the production of the oilseed crop, milling the grain, extracting and refining the oil, transesterification and transportation, as illustrated in Fig. 6.

In the biodiesel production process, vegetable oils are extracted mechanically or by using a solvent, depending on the plant technology, after which the oil is then purified and refined (Bergmann et al., 2013). The industrial stage comprises pretreatment, transesterification and transportation of the biodiesel to the fuel distributor (Milazzo et al., 2013). Transesterification involves the reaction of an oil or fat with an alcohol to form esters and glycerol (Aransiola et al., 2014). The reaction occurs between a triglyceride (oil) and an alcohol, and to increase efficiency and reduce reaction time, a catalyst such as acids, bases or enzymes may be used (Bergmann et al., 2013).

This study analyzes the competitiveness and efficiency of the biodiesel production chain up to the extraction stage of crude vegetable oil from soybean, rapeseed and sunflower, as indicated in Fig. 5. To obtain the final biodiesel, there remain only the stages of refining and transesterification, the values for which were obtained from published studies (Coiro, 2016; Savi and Kochhan, 2016; USDA, 2012).

Biodiesel production costs are strongly influenced by the feedstocks used, the scale of processing plants and tax rates (Duncan, 2003; Hass et al., 2006). Thus, costs can vary significantly due to the diversity of raw materials (soybean, rapeseed, sunflower, cotton, animal fat etc.), the regions where the biodiesel is produced (different tax rates between regions) and the diversity of scales of production in different regions (Padula et al., 2012).

\section{Methods and procedures}

This section presents the method used in the economic analysis of the biodiesel feedstock production systems and chains and the data collection and analysis procedures adopted in this research. The variables and data collected were defined based on the definition of the accounting analysis categories and indicators that the Policy Analysis Matrix (PAM) allows, as shown in Section 2.1, and in accordance with the procedures suggested by Monke and Pearson (1989), Vieira et al. (2001) and Lopes et al. (2012).

The main items specific to the application of the PAM method of economic analysis to the soybean oil, rapeseed and sunflower biodiesel production systems and chains were selected and reported, given the aim of describing their respective competitive situations and the impacts the PNPB policies have on them. To this end, the economic indexes and technological options in the allocation of productive resources in each crop system were considered together with the technical indexes existing in the agricultural crops and processing plants and the tax and incentives policies, as suggested by Monke and Pearson (1989).

The state of Rio Grande do Sul was defined as the geographical boundary of this study, because: i) it is the largest biodiesel producer in Brazil (30\% of the total) and has produced biodiesel from soybean, sunflower and rapeseed for years, which facilitated the collection of data of the production chains under study herein; ii) the agricultural production of oilseeds is technological-intensive, complying with the selection requirements of the representative farms and biodiesel plants for data collection, as established in the PAM approach; iii) the access to agents involved in biodiesel production, such as farmers, processing plants and transporters; iv) and in order to meet the data quality recommendations referred to in Monke and Pearson (1989), Lopes et al. (2012) and Torres et al. (2013).

\begin{tabular}{|c|c|c|c|c|}
\hline \multicolumn{5}{|c|}{ BIODIESEL } \\
\hline SCENARIO & \multirow{3}{*}{ General Rule } & Intensive Farming & Family Farming & Family Farming \\
\hline FEEDSTOCK & & $\begin{array}{c}\text { Castor Bean or } \\
\text { Palm }\end{array}$ & Any & $\begin{array}{c}\text { Castor Bean or } \\
\text { Palm }\end{array}$ \\
\hline REGION & & $\begin{array}{l}\text { North, Northeast or } \\
\text { Semi-arid. }\end{array}$ & Any & $\begin{array}{l}\text { North, Northeast or } \\
\text { Semi-arid. }\end{array}$ \\
\hline $\begin{array}{l}\text { REDUCTION } \\
\text { COEFFICIENT }\end{array}$ & 0.7802 & 0.8129 & 0.9135 & 1.00 \\
\hline PIS/PASEP(1) & $\mathrm{R} \$ 0.026$ & $\mathrm{R} \$ 0.022$ & $\mathrm{R} \$ 0.0104$ & $\mathrm{R} \$ 0.00$ \\
\hline $\operatorname{COFINS}(2)$ & $\mathrm{R} \$ 0.122$ & $\mathrm{R} \$ 0.104$ & $\mathrm{R} \$ 0.0478$ & $\mathrm{R} \$ 0.00$ \\
\hline $\operatorname{CIDE}(3)$ & Non-existent & Non-existent & Non-existent & Non-existent \\
\hline $\operatorname{IPI}(4)$ & Non-existent & Non-existent & Non-existent & Non-existent \\
\hline SUM & $\mathrm{R} \$ 0.148 / 1$ & $\mathrm{R} \$ 0.126 / 1$ & $\mathrm{R} \$ 0.058 / 1$ & $\mathrm{R} \$ 0.00 / 1$ \\
\hline ALIQUOT $\left(\mathrm{R} \$ / \mathrm{m}^{3}\right)$ & $\mathrm{R} \$ 148.00 / \mathrm{m}^{3}$ & $\mathrm{R} \$ 126.00 / \mathrm{m}^{3}$ & $\mathrm{R} \$ 58.24 / \mathrm{m}^{3}$ & Null \\
\hline
\end{tabular}

(1) PIS/PASEP: Programa para a Integração Social do Trabalhador (Worker's Social Integration Program).

(2) COFINS: Contribuição para o Financiamento da Seguridade Social (Social Security Contribution).

(3) CIDE: Contribuições de Intervenção no Domínio Econômico (Economic Domain Intervention Contribution)

- levied on fuel imports (gasoline, kerosene, diesel).

(4) IPI: Imposto sobre Produtos Industrializados (Industrialized Products Tax).

(5) $(\mathrm{R} \$ 2.41=\mathrm{US} \$ 1)$

Fig. 5. Tax reduction and advantages for biodiesel production in Brazil (PNPB). Source: Adapted from Santos (2009). 


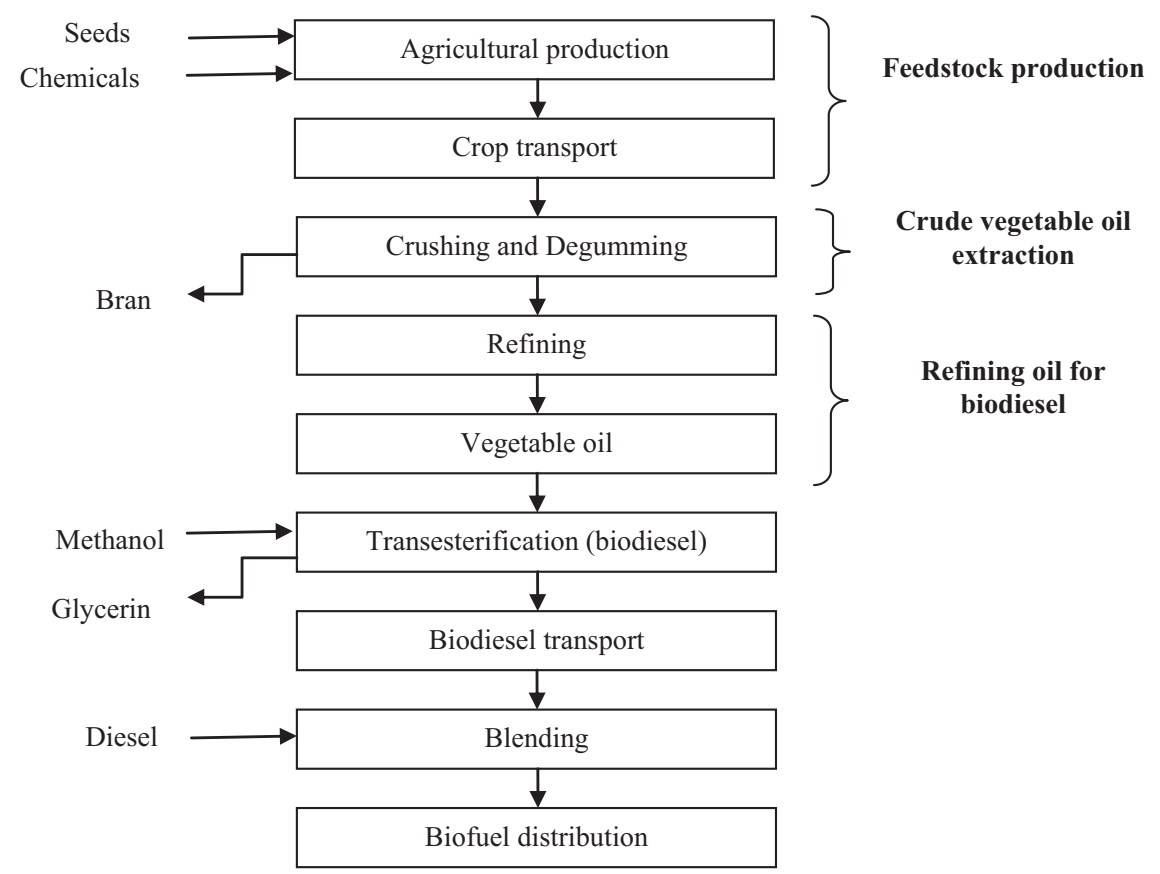

Fig. 6. Technological route of biodiesel production. Source: Adapted from Milazzo et al. (2013).

\subsection{Data collection}

As suggested by Monke and Pearson (1989) and Pearson et al. (2003), in this research it is used exhaustive secondary data to compare and validate the primary data collected in the "representative" production systems. The description of the production systems and chains of the oilseeds used to produce biodiesel is based on the collection of technical, economic and financial information from official secondary sources and market players, as well as from scientific bibliographies, government documents and scholarly articles, together with information on prices paid and received in the international market. Data from primary sources were collected during technical visits to farmers and processing plants, during which complete surveys were conducted on the costs and revenues of each link in the selected production chain according to integrated spreadsheets used in the PAM method, which detail all fixed costs, labor and intermediate inputs in the four links of the production chains, including depreciation and investment opportunity costs, as well as gross and net revenue. The in-person interviews with executives began in October 2014, were conducted with the aid of a script in the form of checklist, and the data collected were checked and consolidated with later investigations and comparisons with other reliable secondary sources.

For each studied production system and chain, the representative establishment (uses the best available technology and adopts appropriate management principles) was previously identified based on information provided by surveys conducted by Embrapa (2014) and universities, extension agents, technical assistants from EMATER-RS (rural extension services) and agricultural credit and insurance organizations, which act directly in the production and marketing of crops, vegetable oil and biodiesel, as suggested by Monke and Pearson (1989) and Pearson et al. (2003).

The studied biodiesel production chains were divided into segments as follows: 1st link, including the agricultural systems and economic activities of the respective soybean, rapeseed and sunflower farmer; 2nd link, comprising the transportation of the grain to the oil extraction and biodiesel processing plant; 3rd link, which constitutes the processing of crude vegetable oil and the biodiesel production; and the 4th link, which is the transport of the biodiesel to the fuel distributor (market) or nearest port of export, as shown in Fig. 7.

The methodological procedures and criteria adopted in this study are in accordance with recent studies that have used the PAM methodology, such as the set of studies presented by Torres et al. (2013), Souza (2014) and Souza et al. (2017). The decision to analyze only one farmer and one processor in the evaluation of the three chains is justified by the prior use of this practice when using PAM in international studies (Lopes et al., 2012). It was collected data from the same farm in which there were soybean, rapeseed and sunflower crops, making the comparison between biodiesel feedstock sources more equitable.

When defining the farmer costs and revenues, the costs per hectare were considered of a representative farm covering $200 \mathrm{ha}$, situated close to a vegetable oil-processing plant and located in the northwest of Rio Grande do Sul region, one of the largest oil-producing areas, and using crop rotation throughout the year, alternating between the production of soybean, corn, sunflower, rapeseed, oats and wheat. In recent years, this farm has regularly grown 180 ha of soybean, $20 \mathrm{~h}$ of rapeseed and $15 \mathrm{~h}$ of sunflower for crude vegetable oil production. For budgeting purposes, in the calculation of the fixed costs, the number of hectares under each crop was taken to indicate the effective partial use of the durable good for the generation of crop per hectare per year to ensure the expression of the allocative efficiency of each resource. In addition, the following variables were considered, the: use of family labor; productivity and price of each ton of grain sold; oil yield of each crop species; prices and quantities of the intermediate inputs used; interest rate operated as the second best investment for the fixed goods; and the assignment of a rental value for inclusion of the annual cost of the land, because of the high price per hectare currently practiced in the region.

In the second link, the average rate charged for transporting a ton of oilseed grain from the field to the vegetable oil processing plant was accounted. In the third link, a representative vegetable oil processing plant was considered, from which data regarding costs, revenues and taxes on the main and secondary products. The latter represented the bran and husk of the grain processed to obtain the vegetables oils. The yield factor for each of the oilseed production chains was used, that is, the amount of oil generated when processing one ton of each feedstock, which is $18 \%$ of the grain weight for soybean, $37 \%$ for rapeseed and $39 \%$ for sunflower.

The data were collected from a representative processing plant (3rd link) which produces crude vegetable oil from the three studied 


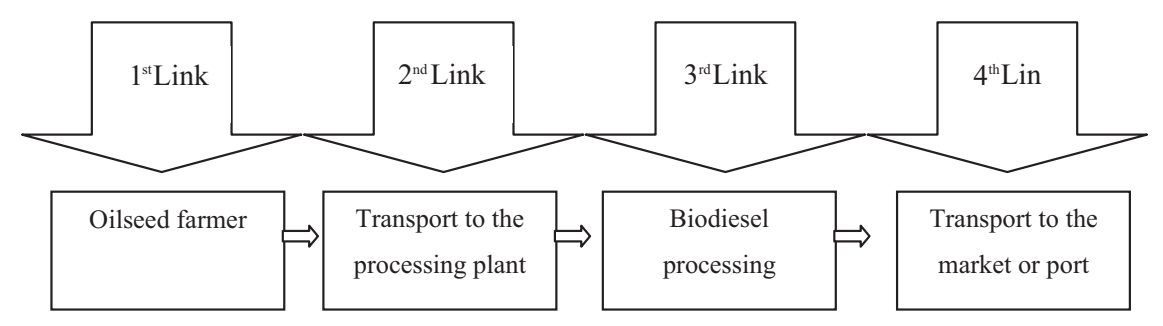

Fig. 7. Links and segments of biodiesel production and marketing chain. Source: Elaborated by the authors.

oilseeds. Included within the vegetable oil production step is that of transesterification, during which biodiesel is produced, as shown in Fig. 7. This study also recorded and then integrated the costs and revenues of transesterification to those of vegetable oil production, based on data obtained and calculated from secondary sources, including BADESUL (2016), the agribusiness financing bank in RS, market operators and those conducted at COPPE-UFRJ (Murta, 2008) and other surveys and research (Araújo et al., 2002; Hass et al., 2006; Lima, 2011). These references suggest the average value of the incremented costs in the transesterification stage stood at around $10 \%$ of the total costs to produce biodiesel.

The study also incorporated the simulation of the impacts of the PNPB on the profitability of the respective production chains, to meet the objective of evaluating the impact of the government benefits and tax exemptions offered to biodiesel producers through the National Program for Production and Use of Biodiesel (PNPB), as shown in Fig. 4. The calculation of the costs and revenues received for the biodiesel followed the market averages and the official prices at the time, which were dollarized at the exchange rate of October 2014. The average price of biodiesel was R $\$ 2.194$ per liter (ANP, 2016), while for the by-product glycerin, data provided by BADESUL (2016) indicated a value of $\mathrm{R} \$ 150.00 / \mathrm{t}$. It should be noted that the crude oil from the oilseed yields $85 \%$ biodiesel, $11 \%$ glycerin and $4 \%$ lees, while the average loss is $2.5 \%$.

The difference in the tax paid (PIS/PASEP and Confins), with and without the presence of the benefits of the PNPB, was included as private income in the third link of the matrix (processing plant) so as to illustrate the reality of the biodiesel industry and the effect of the benefits offered by the Government program (PNPB). The simulation was carried out in the soybean, rapeseed and sunflower chains. The amount of oil was calculated using the formula 'Oil Volume $=1 \mathrm{t} x$ $\left(1 \mathrm{~m}^{3} / 0.92 \mathrm{t}\right.$ )', with a bulk conversion factor of 0.92 being adopted for all the oilseeds. This calculation was necessary because the values of the subsidies mentioned in the Brazilian legislation are referenced in cubic meters. To convert the values expressed in dollars in PAM spreadsheets to Brazilian currency (Real), the average rate of exchange for the period of October 2014, the date of data collection $(\mathrm{R} \$ 2.41=$ US \$ $1 \$ 2.41=$ UR \$ $2.41=$ US \$ 1 \$) was used.

\section{The results presentation and discussion}

This section presents and discusses the results obtained from the spreadsheets built using the Policy Analysis Matrix (PAM) method in soybean, rapeseed and sunflower biodiesel systems and chains in Rio Grande do Sul, considering the absence and the presence of incentives within the context of PNPB and the Social Seal initiative. The analysis focuses on the calculation of costs, revenues, profits, economic efficiency and the effects of public and private policies that are specific to these production systems and chains, such as the degree of protection and the levels of taxation and subsidies.

Table 1 shows the results of applying the PAM method to the four biodiesel chain links for the three raw materials in the agricultural period 2013/2014.

The level of Private Profit identified $[\mathrm{D}=\mathrm{A}-(\mathrm{B}+\mathrm{C})]$ shows the economic viability of the three feedstock production systems and chains, suggesting they are able to compete under the technical, economic and tax conditions of the business environment within which they operate. These results were obtained considering the production of biodiesel without the incentives from the PNPB's Social Seal and reveal that while the three feedstocks are profitable, there are great differences between the returns obtained: $\mathrm{R} \$ 937.62 / \mathrm{t}$ with soybean biodiesel; $\mathrm{R} \$ 783.82 / \mathrm{t}$ with rapeseed biodiesel; and $\mathrm{R} \$ 544.28 / \mathrm{t}$ with sunflower biodiesel (R $\$ 2.41=$ US $\$ 1)$. This result is in line with that of Antunes (2013) and Zonin et al. (2014), who also found that the use of soybean oil to make biodiesel provides more private profit when compared to biodiesel production from castor oil in RS.

The Social Revenues (E) presented in Table 1 represents the values that could approximate the prices of domestic raw materials to international prices, as they were obtained by exempting all taxes and fees considered in the construction of PAM worksheets. The results show there is a burden of approximately $13 \%$ on Private Revenues (EA) and a consequent $50 \%$ decrease in profits (H-D) for farmers and

Table 1

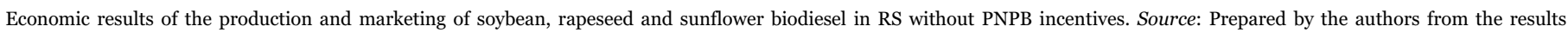
obtained with the integrated spreadsheets method of the Policy Analysis Matrix (PAM). (R \$ $2.41=$ US \$ 1 ).

\begin{tabular}{|c|c|c|c|c|c|c|}
\hline & & \multirow[b]{2}{*}{ Revenue (R $\$ / t)$} & \multicolumn{2}{|c|}{ Costs $(\mathrm{R} \$ / \mathrm{t})$} & \multirow[b]{2}{*}{ Domestic factors } & \multirow[b]{2}{*}{ Profit $(\mathrm{R} \$ / \mathrm{t})$} \\
\hline & & & Inputs & Tradables & & \\
\hline & Private & $\mathbf{A}$ & $\mathbf{B}$ & & $\mathbf{C}$ & D \\
\hline Soybean & & $2,447.16$ & 995.40 & & 514.14 & 937.62 \\
\hline Rapeseed & & $1,799.30$ & 810.87 & & 204.61 & 783.82 \\
\hline \multirow[t]{2}{*}{ Sunflower } & & $1,616.27$ & 846.53 & & 225.46 & 544.28 \\
\hline & Social & $\mathbf{E}$ & $\mathbf{F}$ & & G & $\mathbf{H}$ \\
\hline Soybean & & $2,817.09$ & 945.49 & & 48.91 & 1.822 .69 \\
\hline Rapeseed & & $2,040.76$ & 769.21 & & 52.66 & 1.218 .89 \\
\hline \multirow[t]{2}{*}{ Sunflower } & & $1,831.01$ & 802.53 & & 49.05 & 979.43 \\
\hline & Divergence effects & I & $\mathbf{J}$ & & $\mathbf{K}$ & $\mathbf{L}$ \\
\hline Soybean & & $(366.93)$ & 49.91 & & 464.23 & (885.07) \\
\hline Rapeseed & & (241.46) & 41.68 & & 151.95 & (435.07) \\
\hline Sunflower & & $(214.73)$ & 44.00 & & 176.41 & (435.15) \\
\hline
\end{tabular}


Table 2

Relationship between agricultural yield $(\mathrm{t} / \mathrm{ha})$ and profitability $(\mathrm{R} \$ / \mathrm{t})$ in soybean, rapeseed and sunflower biodiesel production in the RS, without the PNPB incentives. Source: Prepared by the authors based on data obtained from the studied farm. (R $\$ 2.41$ $=$ US\$1).

\begin{tabular}{lllll}
\hline $\begin{array}{l}\text { Biodiesel } \\
\text { feedstock }\end{array}$ & $\begin{array}{l}\text { Agricultural } \\
\text { yield (t/ha) }\end{array}$ & $\begin{array}{l}\text { Private } \\
\text { Profit D (R } \\
\$ / \mathrm{t})\end{array}$ & $\begin{array}{l}\text { Social } \\
\text { Profit H (R } \\
\$ / \mathrm{t})\end{array}$ & $\begin{array}{l}\text { Profit reduction or } \\
\text { transference (\%) }\end{array}$ \\
\hline Soybean & 2.58 & 1.007 .34 & 2.516 .88 & -60.00 \\
Rapeseed & 1.56 & 814.23 & 1.829 .67 & -55.50 \\
Sunflower & 1.38 & 574.40 & 1.642 .38 & -65.00 \\
\hline
\end{tabular}

owners of soybean, rapeseed and sunflower processing plants due to market failures. In this case, it is represented by tax impositions that is transformed in income transferred from the studied agro-industrial sector to other sectors of society. Private Profits (D), according to the conceptualization underpinning the PAM method, should be as close as possible to Social Profits $(\mathrm{H})$.

The presence of negative values ( $R \$ 885.07 / t, R \$ 435.07 / t, R$ $\$ 435.15 / t)$ for the Divergence Effects on profits $[\mathrm{L}=(\mathrm{D}-\mathrm{H})]$ means that the three biodiesel production systems and chains are competitive and achieve profits without the need for subsidies. On the other hand, the presence of negative values $(\mathrm{R} \$ 366.93 / \mathrm{t}, \mathrm{R} \$ 241.46 / \mathrm{t}, \mathrm{R} \$ 214.73 / \mathrm{t})$ for the Divergence Effects on revenues $[\mathrm{I}=(\mathrm{A}-\mathrm{B})]$ demonstrates that these systems and chains have seen their revenues reduced due to market distortions (tax on machinery and equipment, land prices, tax on intermediate or tradable inputs, social charges related to labor and other market distortions).

Table 2 shows the relationship between the profit at the end of the production chain and agricultural yield, where the higher the yield of grain crops in the respective production system ( $t / h a)$, the greater the profitability (D), considering the current payment system to farmers. The superiority of soybean as a biodiesel feedstock appears to be related to the productivity of these oilseeds in the analyzed production farms, which recorded average yields of $2.58 \mathrm{t} / \mathrm{ha}$ for soybeans, $1.56 \mathrm{t} /$ ha for rapeseed and $1.38 \mathrm{t} /$ ha for sunflower. Productivity is directly related to technological innovation policy of the farmers in the analyzed feedstocks: the more technology and the better the management, as in the case of soybean, the greater the productivity of the oilseed and hence the higher the profitability. The current system of farm's revenue is based on average yields ( $t / h a)$. The value of the oil content is not fully passed to the farmers. In the present revenue system ( $t / h a)$, soybean (18\% of oil content) is preferred as a feedstock over others that provide higher oil content, $37 \%$ for rapeseed and $39 \%$ sunflower. This factor constitutes an obstacle to the development of these alternative chains (rapeseed and sunflower), inhibiting the advance of diversification in the production and marketing of biodiesel.

The difference between the current profit (private profit D) and that which would exist in the absence of taxes and other market failings (social profit $\mathrm{H}$ ) appears to be high for the three biodiesel production systems and chains: $-60.00 \%$ for soybean, $-55.50 \%$ for rapeseed and $-65.00 \%$ for sunflower. As commented above, these numbers reveal that the three supply chains are overcharged and transferring substantial resources to other economic sectors.

With regard to economic performance, expressed in terms of allocative efficiency of the productive resources in the chains in relation to prices received, calculated in the PAM based on the costs, revenue and social profits, soybean biodiesel also had the greater comparative advantage - i.e. in the situation without taxes and market distortions, profit should be $\mathrm{R} \$ 2516.88 / \mathrm{t}$ for biodiesel from soybean, $\mathrm{R} \$ 1829.67 / \mathrm{t}$ for rapeseed and R $\$ 1642.38$ for sunflower. According to Table 2, the negative effects of public policies, market distortions and transfers in the three biodiesel production systems and chains clearly point to the need to review public and private policies in order to raise the efficiency and competitiveness of the raw materials, especially rapeseed and sunflower. A according to Lopes et al. (2012), these divergences reduce the earnings of biodiesel producing agents, weaken the ability to face international competition and discourage farmers from expanding the production and use of alternatives feedstock to soybean. It is noteworthy that Zonin et al. (2014), when analyzing the production of biodiesel from soybean and castor oil, also found differences between private prices and social prices as well as revenue and profit, noting the superiority of the international or social price in relation to that practiced in the domestic market.

The production, marketing and use of biodiesel is new in Brazil and, apart from other reasons of a social nature, there are also specific agricultural and industrial policies in place to encourage its production and consumption. The benefits made to the sector consist of credit, subsidies and research facilities to encourage the adoption of the Social Seal for raw materials purchased from family famers. However, the impacts of the PNPB policy of additional payments for oilseeds produced on small farms remains unknown. Therefore, the contribution of this financial incentive to the results of biodiesel production from soybean, rapeseed and sunflower were evaluated, by simulating the profitability and economic indicators with the presence of that incentive, as shown in Table 3. The data used are almost the same as those in Table 1, only with the modifications resulting from the impact of the inclusion of Social Seal incentives (R $\$ 91.00 /$ ton of grain) and the tax reductions foreseen with the PNPB presented in Fig. 5.

Overall, there were changes in the accounting framework of the PAM with the presence of this PNPB financial incentive, as shown in Table 3. The research results indicate the biodiesel production from the three oilseed is competitive with a profit of $\mathrm{R} \$ 1007.34 / \mathrm{t}$ for soybean, $\mathrm{R}$ $\$ 814.23 / \mathrm{t}$ for rapeseed and $\mathrm{R} \$ 574.40 / \mathrm{t}$ for sunflower $(\mathrm{R} \$ 2.41=\mathrm{US} \$$ 1). The superiority of the profitability of biodiesel production from soybean is notable, as this chain is well organized, more economically efficient and more competitive. With the inclusion of the tax benefits and subsidies offered by the PNPB, private profit (D) increased considerably for the three feedstocks (Private Profits (D) in Table 3 minus Private Profits (D) in Table 1)/ (Private Profits (D) in Table 1): soybean (7.43\%), rapeseed (3.88\%) and sunflower (5.53\%). Biodiesel from soybean benefited the most.

Another set of results from the economic evaluations of the three biodiesel feedstocks is shown in Table 4, with details of the economic performance indicators produced by PAM, with and without the tax incentives offered by PNPB

The share of profits in the revenue (SPR) measures a chain's

\section{Table 3}

Economic results of the production and marketing of crude vegetable oil in $\mathrm{R} \$ /$ ton, to obtain biodiesel from soybeans, rapeseed and sunflower in the RS, with the PNPB incentives. Source: Prepared by the authors from the results obtained using the integrated spreadsheets in Excel of the Policy Analysis Matrix (PAM) method. (R\$ $2.41=$ US\$1).

\begin{tabular}{|c|c|c|c|c|c|}
\hline \multirow[b]{2}{*}{ Feedstock } & & \multirow{2}{*}{$\begin{array}{l}\text { Revenue (R } \\
\$ / \mathrm{t})\end{array}$} & \multicolumn{2}{|c|}{ Costs $(\mathrm{R} \$ / \mathrm{t})$} & \multirow{2}{*}{$\begin{array}{l}\text { Profits (R } \\
\$ / \mathrm{t})\end{array}$} \\
\hline & & & Tradable & Domestic & \\
\hline & Private & $\mathbf{A}$ & $\mathbf{B}$ & $\mathbf{C}$ & $\mathbf{D}$ \\
\hline Soybean & & $2,516.88$ & 995.40 & 514.14 & $1,007.34$ \\
\hline Rapeseed & & $1,829.67$ & 810.87 & 204.61 & 814.23 \\
\hline \multirow[t]{2}{*}{ Sunflower } & & $1,642.38$ & 846.53 & 225.46 & 574.40 \\
\hline & Social & $\mathbf{E}$ & $\mathbf{F}$ & G & H \\
\hline Soybean & & $2,817.09$ & 945.49 & 48.91 & $1,822.69$ \\
\hline Rapeseed & & $2,6040.76$ & 769.21 & 52.66 & $1,215.69$ \\
\hline \multirow[t]{2}{*}{ Sunflower } & & $1,831.01$ & 802.53 & 49.05 & 979,28 \\
\hline & Divergent & I & $\mathbf{J}$ & $\mathbf{K}$ & $\mathbf{L}$ \\
\hline Soybean & effects & $(300.21)$ & 49.90 & 465.23 & (815.35) \\
\hline Rapeseed & & (211.09) & 41.66 & 151.95 & (401.46) \\
\hline Sunflower & & (188.62) & 44.00 & 172.41 & (404.88) \\
\hline
\end{tabular}


Table 4

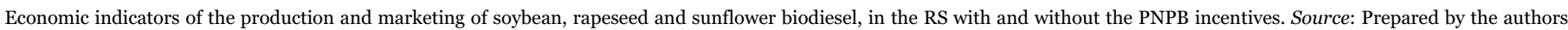
from the results obtained using the integrated spreadsheets in Excel of the Policy Analysis Matrix (PAM) method.

\begin{tabular}{|c|c|c|c|c|c|c|c|}
\hline \multicolumn{2}{|c|}{ INDICATORS } & \multicolumn{2}{|l|}{ SYBEAN } & \multicolumn{2}{|l|}{ RAPESEED } & \multicolumn{2}{|c|}{ SUNFLOWER } \\
\hline Price & Formula & With PNPB & Without PNPB & With PNPB & Without PNPB & With PNPB & Without PNPB \\
\hline \multicolumn{8}{|c|}{ Share of profits in the revenue (SPR) (\%) } \\
\hline Private & $(\mathrm{D} / \mathrm{A})^{*} 100$ & 40,02 & 38,31 & 44,5 & 43,56 & 34,73 & 33,68 \\
\hline Social & $(\mathrm{H} / \mathrm{E})^{*} 100$ & 64,70 & 64,70 & 59,73 & 59,73 & 53,49 & 53,49 \\
\hline \multicolumn{8}{|c|}{ Share of added value in the revenue (SAVR) (\%) } \\
\hline Private & $((\mathrm{A}-\mathrm{B}) / \mathrm{A})^{*} 100$ & 60,45 & 59,32 & 55,68 & 54,93 & 48,46 & 47,62 \\
\hline Social & $((\mathrm{E}-\mathrm{F})) / \mathrm{E})^{*} 100$ & 66,44 & 66,44 & 62,31 & 62,31 & 56,17 & 56,17 \\
\hline \multicolumn{8}{|c|}{ Share of the domestic factors for the added value (SDFAV) (\%) } \\
\hline Private & $(\mathrm{C} /(\mathrm{A}-\mathrm{B}))^{*} 100$ & 33,79 & 35,41 & 20,08 & 20,70 & 28,33 & 29,29 \\
\hline Social & $(\mathrm{G} /(\mathrm{E}-\mathrm{F}))^{*} 100$ & 2,61 & 2,61 & 4,14 & 4,14 & 4,77 & 4,77 \\
\hline \multicolumn{8}{|c|}{ Total productivity of the factors (TPF) } \\
\hline Private & $\mathrm{A} /(\mathrm{B}+\mathrm{C})$ & 1,67 & 1,62 & 1,80 & 1,77 & 1,53 & 1,51 \\
\hline Social & $\mathrm{E} /(\mathrm{F}+\mathrm{G})$ & 2,83 & 2,83 & 2,48 & 2,48 & 2,15 & 2,15 \\
\hline \multicolumn{8}{|c|}{ Nominal protection coefficient of the product (NPCP) } \\
\hline & $\mathrm{A} / \mathrm{E}$ & 0,89 & 0,87 & 0,90 & 0,88 & 0,90 & 0,88 \\
\hline \multicolumn{8}{|c|}{ Nominal protection coefficient of the input (NPCI)) } \\
\hline & $\mathrm{B} / \mathrm{F}$ & 1,05 & 1,05 & 1,05 & 1,05 & 1,05 & 1,05 \\
\hline \multicolumn{8}{|c|}{ Effective protection coefficient (EPC) (\%) } \\
\hline & $(\mathrm{A}-\mathrm{B}) /(\mathrm{E}-\mathrm{F})$ & 0,81 & 0,78 & 0,80 & 0,78 & 0,77 & 0,75 \\
\hline \multicolumn{8}{|c|}{ Vulnerability of the chain to the policies (VCP) } \\
\hline & $((\mathrm{H}-\mathrm{D}) / \mathrm{H}) * 100$ & 44,73 & 48,56 & 33,20 & 35,69 & 41,76 & 44,43 \\
\hline \multicolumn{8}{|c|}{ Profitability coefficient (PC) } \\
\hline & $\mathrm{D} / \mathrm{H}$ & 0,55 & 0,51 & 0,67 & 0,64 & 0,58 & 0,56 \\
\hline \multicolumn{8}{|c|}{ Level of taxation in the chain (LTC) (\%) } \\
\hline & $(\mathrm{L} / \mathrm{E})^{*}(-1)^{*} 100$ & 28,94 & 31,42 & 19,83 & 21,32 & 22,34 & 23,77 \\
\hline
\end{tabular}

survival capacity (Lopes et al., 2012). The inclusion of the PNPB incentives generates a small increase in the share of private profits (SPR) in the production of biodiesel from the three oilseeds, from $38.31 \%$ to $40.02 \%$ for soybean biodiesel, from $43.56 \%$ to $44.50 \%$ for rapeseed biodiesel and from $33.68 \%$ to $34.73 \%$ for sunflower biodiesel. These figures show profits form a considerable part of the revenues in the three production chains, with a slight superiority for rapeseed and soybean biodiesel over sunflower biodiesel.

Added value in each biodiesel feedstock production system and chain was calculated according to the share of added value in the revenues (SAVR). The results express the level of innovation in the agricultural system, which is represented here by the use of inputs and other technologies or knowledge and which was higher in soybean production (60.45\%) than in rapeseed (55.68) and sunflower (48.46\%). The share of domestic factors (SDFAV) reveals that the soybean biodiesel chain has the highest share of the private costs of production factors in the added value (33.79\%) compared to the biodiesel from rapeseed (20.08\%) and sunflower (28.33\%). These indicators confirm the greater competitiveness of the soybean biodiesel chain.

Another economic indicator that was calculated, which consists in measuring the allocative efficiency of the studied production systems and chains, was the private total productivity of the production factors (TPF), obtained from the ratio between the total value of the product (A) and the total value of the costs of the productive resources (intermediate inputs plus domestic factors, B + C)). The current TPF values indicate that the rates of productivity for the production and marketing are $1.67 \%$ for soybean biodiesel; $1.80 \%$ for rapeseed and $1.53 \%$ for sunflower. These productivity levels indicate that this economic activity in the three chains could have consistent growth, corroborating the studies of Wang et al. (2015), who identified an average TPF of $1.49 \%$ per annum for the US agribusiness between the years 1948 and 2011, which the authors concluded constituted strong growth that allowed North American agriculture to more than double in size during that period.

As regards the effects of government policies, the results of the distortions throughout the agricultural systems and chains, the nominal (NPCP) and effective protection coefficients (EPC) of soybean, rapeseed and sunflower, with values below 1.00, indicate that even with the incentives and tax reductions offered by the PNPB, there are significant distortions (public policies, taxes, market inefficiencies) in the production of biodiesel, with very similar values for the three oilseeds (EPC $0.81 \%$ for soybean; $0.80 \%$ for rapeseed and $0.77 \%$ for sunflower). These distortions negatively influence competitive ability in economically free and market economy environments. As for the impact of taxes, contributions and fees on the competitiveness of the chains (LTC), although the incentives and tax exemptions conceded by the PNPB have improved competitiveness, due to the reduction in the tax burden (LTC) in the soybean (from $31.42 \%$ to $28.94 \%$ ), rapeseed (from $21.32 \%$ to $19.83 \%$ ) and sunflower (from $23.77 \%$ to $22.34 \%$ ) biodiesel chains, taxes and fees remain a considerable loss of competitiveness for the three agricultural systems and chains.

\section{Concluding remarks and policy and managerial implications}

Using the Policy Analysis Matrix, this study identified and analyzed the indicators of economic efficiency, competitiveness and the impact of the National Program for Biodiesel Production (PNPB in Portuguese) policy on biodiesel production systems and chains based on three oilseeds, namely soybean, rapeseed and sunflower. The data were collected from a single representative agricultural establishment (uses the best available technology and adopts appropriate management principles) and a diversified biodiesel production plant located in the Northwest of Rio Grande do Sul state (the largest biodiesel producer). The effects of the incentives provided by the Social Seal for Family Farming within the PNPB were also quantified and analyzed.

The research results (Table 3 ) indicate the biodiesel production from the three oilseed is competitive and feasible with a profit of $\mathrm{R}$ $\$ 1007.34 / \mathrm{t}$ for soybean, $\mathrm{R} \$ 814.23 / \mathrm{t}$ for rapeseed and $\mathrm{R} \$ 574.40 / \mathrm{t}$ for sunflower $(\mathrm{R} \$ 2.41=$ US $\$ 1)$. The tax reductions and subsidies provided by the PNPB have a positive impact on the profitability of biodiesel production chains: $7.43 \%$ for soybean, $3.88 \%$ for rapeseed, and $5: 53 \%$ for sunflower. The superiority of the profitability of 
biodiesel production from soybean is notable, as this chain is well organized, more economically efficient and more competitive.

The profitability and competitiveness of the studied biodiesel feedstocks suffer the effects of market distortions (interest, taxation of inputs and machinery, social charges of labor and social contributions, etc.) identified based on the difference between the values in the domestic (private profit) and international (social profit) markets. Table 3 shows the gap between the social profit that would be obtained in the absence of distortive policies and the private profit was $\mathrm{R}$ $\$ 815.35 / \mathrm{t}$ for soybean, $\mathrm{R} \$ 401.46 / \mathrm{t}$ for rapeseed and $\mathrm{R} \$ 404.88 / \mathrm{t}$ for sunflower $(\mathrm{R} \$ 2.41=\mathrm{US} \$ 1)$. These distortions reveal the need for a possible correction to the policy of incentives for oilseed diversification to focus on reducing this taxation in order to better use the availability of productive resources in the various productive and poorest regions in the country.

The current system of farm's revenue is based on average yields ( $t$ / ha). The superiority of soybean as a biodiesel feedstock appears to be related to the productivity of this oilseed $(2.58 \mathrm{t} / \mathrm{ha})$ compared to $1.56 \mathrm{t} / \mathrm{ha}$ for rapeseed and $1.38 \mathrm{t} / \mathrm{ha}$ for sunflower. The value of the oil content is not fully passed to the farmers. In the present revenue system ( $t / h a)$, for the farmers soybean ( $18 \%$ of oil content) is preferred as a feedstock over others that provide higher oil content, $37 \%$ for rapeseed and 39\% sunflower. This factor constitutes an obstacle to the development of these alternative chains (rapeseed and sunflower), inhibiting the advance of diversification in the production and marketing of biodiesel. Thus, redesigning the PNPB policies, so as to change the system of payments to farmers and also provide direct tax incentives and subsidies to farmers could increase the productivity of rapeseed and sunflower and lead to the better use of land and other idle productive resources in the off season (winter and spring), with the use of crop rotation. Payment to the farmers based on the amount of oil generated per hectare, rather than by volume of grains, would also contribute to the expansion alternative crops for biodiesel production.

The research results are encouraging. The technical and economic indicators identified in the representative supply chain (uses the best available technology and adopts appropriate management principles) suggest investments in technology, training farmers, and organizing/ coordinating alternative oilseed chains (castor bean, rapeseed, sunflower, palm) designed to improve the productivity and profitability are worthwhile.

In contrast to the papers that have presented results of experimental biodiesel production initiatives using alternative oilseeds (cited in the Introduction Section (1)), this paper explores the case of a "representative" production chain in Rio Grande do Sul, the leading biodiesel producing state in Brazil. The economic and production indicators identified in this study can be considered of good quality, as suggested by Monke and Pearson (1989) and Pearson et al. (2003), and could be taken into account when considering any revision of the PNPB's incentive policies and the investment decisions regarding the production systems and alternative oilseed chains (rapeseed, sunflower) with a view to diversify the raw materials for biodiesel production in Brazil.

It can be signaled some of the research's limitations and future prospects. The National Program for Biodiesel Production (PNPB) is in infancy. It needs a little more time to have a more representative evaluation of the program's effectiveness. Considering the diversity of climate, land fertility and the alternative feedstocks in Brazil (castor bean, rapeseed, sunflower, jatropha, animal fat) we suggest further research in the different regions and different production scales and technologies that can contribute to have a more extended evaluation of the PNPB.

In addition to economic feasibility analysis, further studies are also needed to quantify the socio-environmental impacts and the major economic and ecosystem benefits of biofuels uses in relation to fossil fuels. The structure of the PAM approach mean it is suitable for determining the monetary value of the effects of policies intended to protect and conserve the environmental goods and services associated with the production and commercialization of biofuels (Belarmino et al., 2015; FAO, 2007).

While the focus of the paper is to highlight the Brazilian experience on the production of biodiesel, the results suggest there are lessons that can be exploited by other countries that may be considering introducing biodiesel into their energy mix.

\section{Acknowledgments}

The authors are grateful for the support provided by the Brazilian agencies CAPES, CNPq (Processo n. 303994/2015-0) and EMBRAPA. The authors would like to thank the two anonymous reviewers for the useful comments and suggestions.

\section{References}

ABIOVE, 2016. Associação Brasileira das Indústrias de Óleos Vegetais. Produção de biodiesel por matéria-prima. ANP/ABIOVE - Coordenadoria de Economia e Estatística. 〈http://www.abiove.org.br/site/index.php?Page=estatistica \& area $=\mathrm{NC} 0 \mathrm{yLTE}=>$. (Accessed 21 June 2016)

Agenciabrasil, 2016. Brazil renewable energy matrix reachs $41.2 \%$ in 2016. 〈http:// agenciabrasil.ebc.com.br/en/economia/noticia/2016-06/brazil-share-renewableenergy-matrix-reaches-412 . (Accessed 10 February 2017.

ANP, 2015. Agência Nacional de Petróleo, Gás Natural de Biocombustíveis. Superintendência de Pesquisa e Desenvolvimento Tecnológico. Produção Nacional de Biodiesel Puro B100 (metros cúbicos). 2005-2015. 〈www.anp.gov.br〉. (Accessed on 29 Mai 2015).

ANP, 2016. Agência Nacional do Petróleo, Gás Natural e Biocombustíveis. Produção Nacional de Biodiesel Puro - B100 (barris equivalentes de petróleo). Produção de biodiesel - B100 por produtor e por estado 2005-2016 (bep). 2016. 〈www.anp.gov. $\mathrm{br} /$ ? Dw=8739 $\rangle$. (Accessed 22 June 2016).

Antunes, V.N.B., 2013. Análise de competitividade e eficiência da cadeia produtiva do biodiesel no Brasil utilizando a PAM. Rev. Bras. Energia 19 (2), 119-140.

Aransiola, E.F., Ojumu, T.V., Oykola, O.O., Adzimbamuto, T.F., Ikhu-Omoregbe, D.I.O., 2014. A review of current technology for biodiesel production: state of the art. Biomass Bionergy 61, 276-297. http://dx.doi.org/10.1016/j.biombioe.2013.11.014.

Araújo, K.M., Oliveira, A.K.C., Costa, G.B., Queiroga, R.N.G., Pannir Selvam, P.V., 2002. Estudo comparativo técnico e econômico de diferentes óleos vegetais brasileiros para produção de biocombustível. Enc. Energ. Meio Rural 4, 1-9 〈http://www. proceedings.scielo.br/pdf/agrener/n4v2/069.pdf .

Auer, B.R., 2016. How does Germany's green energy policy affect electricity market volatility? An application of conditional autoregressive range models. Energy Policy 98, 621-628.

BADESUL, 2016. 〈http://www.badesul.com.br/〉. (Accessed 9 Mai 2015).

Belarmino, L.C., Lima Filho, J.R., Cuenca, E., Pabsdorf, M.N., 2015. Uso da MAP Ambiental na valoração das degradações e externalidades ambientais na produção de maçãs. In: Tosto, S.G. , Bellarmino, L.C. , Romeiro, A.R. , Rodrigues, C.A.G. (Editores), 2015. Valoração de serviços ecossistêmicos; Metodologias e estudos de caso. Brasília-DF, Embrapa-SCI, 189-205.

Bergmann, J.C., Tupinambá, D.D., Costa, O.Y.A., Almeida, J.R.C., Barreto, C.C., Quirino, B.F., 2013. Biodiesel production in Brazil and alternative biomass feedstocks. Renew. Sustain. Energy Rev. 21, 411-420. http://dx.doi.org/10.1016/ j.rser.2012.12.058.

Besi, M., McKormic, K., 2015. Towards a bioeconomy in Europe: national, regional and industrial strategy. Sustainability 7, 10461-10479. http://dx.doi.org/10.33/ su70810461.

Bhattacharya, M., Paramati, S.R., Ozturk, I., Bhattacharya, S., 2016. The effect of renewable energy consumption on economic growth: evidence from top 38 coutries. Appl. Energy 162, 733-741. http://dx.doi.org/10.1016/j.apenergy.2015.10.104.

BRASIL, 1966. Lei no 5. 172, de 25 de outubro de 1966. Dispõe sobre o sistema tributário nacional e institui normas gerais de direito tributário aplicáveis à união, estados e municípios. Diário Oficial da República Federativa do Brasil, Brasília, DF, 27 out. 1966. Seção 1, p.1245. 〈http://www.receita.fazenda.gov.br/Legislacao/ CodTributNaci/ctn.htm $\rangle$. (accessed 15 June 2013).

Brown, J.H., et al., 2014. Macroecology meets macroeconomics: resources scarcity and global sustainability. Ecol. Eng. 65, 24-32. http://dx.doi.org/10.1016/ j.ecoleng.2013.07.071.

Castiblanco, C., Moreno, A., Etter, A., 2015. Impact of policies and subsidies in agribusiness: the case of palm and biofuels in Colombia. Energy Econ. 49, 676-686. http://dx.doi.org/10.1016/j.eneco.2015.02.025.

César, A.S., Batalha, M.O., 2010. Biodiesel production from castor oil in Brazil: a difficult reality. Energy Policy 38, 4031-4039. http://dx.doi.org/10.1016/ j.enpol.2010.03.027.

César, A.S., Batalha, M.O., 2011. Análise dos direcionadores de competitividade sobre a cadeia produtiva de biodiesel: o caso da mamona. Produção 21 (3), 484-497. http:// dx.doi.org/10.1590/S0103-65132011005000039.

César, A.S., Batalha, M.O., Zopelari, A.L.M.S., 2013. Oil palm biodiesel: Brazil's main challenges. Energy 60, 485-491. http://dx.doi.org/10.1016/j.energy.2013.08.014.

Coiro, F., 2016. Clima e preços favoráveis. Zero Hora, Campo e Lavoura, 28/06/2016. 
Colussi, J., 2014. 〈http://zh.clicrbs.com.br/rs/noticias/campo-e-lavoura/noticia/2014/ 06/mudanca-no-oleo-diesel-estimula-plantio-da-rapeseed-no-rio-grande-do-sul4526498.html $>$. (Accessed 5 September 2014).

Dal Belo Leite, J.G., Bijman, J., Giller, K., Slingerland, M., 2013. Biodiesel policy for family farms in Brazil: one-size-fits-all? Environ. Sci. Policy 27, 195-205. http:// dx.doi.org/10.1016/j.envsci.2013.01.004.

Dal Belo Leite, J.G., Justino, F.B., Silva, J.V., Florin, M.J., Van Ittersum, M.K., 2015. Socioeconomic and environmental assessment of biodiesel crops on family farming systems in Brazil. Agric. Syst. 133, 22-34. http://dx.doi.org/10.1016/ j.agsy.2014.10.005.

Dal Belo Leite, J.G., Silva, J.V., Van Ittersum, M.K.,, 2014. Integrated assessment of biodiesel policies aimed at Family farms in Brazil. Agric. Syst. 131, 63-76. http:// dx.doi.org/10.1016/j.agsy.2014.08.004.

Drabik, D., Gorter, H., Timilsina, G.R., 2014. The effect of biodiesl policies on world biodiesel and oilseed prices. Energy Econ. 44, 80-88. http://dx.doi.org/10.1016/ j.eneco.2014.03.024.

Duncan, J., 2003. Cost of biodiesel production. 〈http://www.globalbioenergy.org/ uploads/media/0305_Duncan_-_Cost-of-biodiesel-production.pdf $\rangle$. (Accessed 9 June 2015).

EMBRAPA, 2014. Rapeseed em números. 〈http://www.cnpt.embrapa.br/pesquisa/ economia/2014 04 RAPESEEDnumeros.pdf $\rangle$. (Accessed 9 September 2015).

Fagundes, P.M., Padula, A.D., Padilha, A.C.M., 2016. Interdependent international relations and the expansion of etanol production and consumption: the Brazilian perspective. J. Clean. Prod. 133, 616-630. http://dx.doi.org/10.1016/ j.jclepro.2016.05.006.

FAO, 2007. Competitividad de la agricultura en América Latina y Caribe. Matriz de Análisis de Política: Ejercicios de Cómputo. FAO-RLC, Santiago de Chile, 2007. 112 p. 〈http://www.rlc.fao.org/uploads/media/map.pdf〉. (accessed 2 April 2017).

Farla, K., 2015. Industrial policy for growth. J. Ind. Compét. Trade 15, 257-282. http:// dx.doi.org/10.1007/s10842-014-0183.

Ferraz, J.C., Kupfer, D., Haguenauer, L., 1996. Made in Brazil: desafios competitivos para a indústria brasileira. Ed. Campus, Rio de Janeiro.

Florin, M.J., Van Ittersum, M.K., Van de Ven, G.W.J., 2013. Family farmers and biodiesel production: systems thinking and multi-level decisions in Norther Minas Gerais, Brazil. Agric. Syst. 121, 81-95. http://dx.doi.org/10.1016/j.agsy.2013.07.002.

Gebreegziabher, Z., Mekonnen, A., Ferede, T., Guta, F., Levin, J., Köhlin, G., Alemu, T., Bohlin, J., 2013. The distributive effect and food security implications of biofuels investimento in Ethiopia: a CGE analysis. Environment for Development, Discussion Paper 13-02. 〈http://www.efdinitiative.org/sites/default/files/efd-dp-13-02-1_0. pdf). (Accessed 10 April 2016).

Hass, M.J., McAloon, A.J., Yee, W.C., Foglia, T.A., 2006. A process model to estimate biodiesel production costs. Bioresour. Technol. 97, 671-678. http://dx.doi.org/ 10.1016/j.biotech.2005.03.039.

Kennedy, P.L., Harrison, R.W., Piedra, M.A., 1998. Analysing Agribusiness competitiveness: case of the United States sugar industry. Int. Food Agribus. Manag. Rev. 1 (2), 245-257.

Kiyota, K., Okazaki, T., 2016. Assessing the effects of Japonese industrial policy change during the 1960s. J. Jpn. Int. Econ. 40, 31-32. http://dx.doi.org/10.1016/ j.ijie.2016.03.005.

Latruffe, L., 2010. Competitiveness, productivity and efficiency in the agricultural and agri-food sectors. OECD Food Agric. Fish. Pap. (30), 1-63.

Lazzarini, S.G., 2015. Strategizing by the government: can industrial policy create firmlevel competitive advantage? Strateg. Manag. J. 36, 97-112. http://dx.doi.org/ 10.1002/smj.2204.

Liefert, W.M., Westcott, P.C., 2015. Alternative policies to agricultural export taxes that are less market distorting, ERR-187, U.S. Department of Agriculture, Economic Research Service, June 2015.

Lima, A.M., 2011. Estudos recentes e perspectivas da viabilidade técnico-econômica da produção de biodiesel. Embrapa Agroenergia, Brasilia-DF., Documentos, 008, 2011.

Liu, J.Y., Xia, Y., Fan, Y., Lin, S.-M., Wu, J., 2015. Assessment of a green credit policy aimed at energy-intensive industries in China based on a financial CGE model. J. Clean. Prod.. http://dx.doi.org/10.1016/j.jclepro.2015.10.111, (in press).

Lopes, M.R., Belarmino, L.C., Oliveira, A.J., Lima Filho, J.R., Talamini, J.D.D., Martins, F.M., 2012. Matriz de análise de política. Metodologia e análise. Embrapa, BrasíliaDF, 227.

MDA, 2012. Ministério de Desenvolvimento Agrário. O Selo do Combustível Social. 〈www.mda.gov.br/portal/saf/programas/biodiesel/2286313〉. (Accessed 24 April 2015).

MDA, 2015. Ministério do Desenvolvimento Agrário. Biodiesel, 〈www.mda.gov.br/〉. (Accessed 3 December 2015).

Milazzo, M.F., Spina, F., Primerano, P., Bart, J.C.J., 2013. Soy biodiesel patwhways: global prospects. Renew. Sustain. Energy Rev. 26, 579-624. http://dx.doi.org/ 10.1016/j.rser.2013.05.056.

Mjimba, V., 2015. A case for industrial policy towards green economy transition in developing economies. Afr. Insight 45 (3), 76-90.

MME, 2004. Ministério das Minas e Energias. Programa Nacional de Produção e Uso de Biodiesel (PNPB). 〈http://www.mme.gov.br/programas/biodiesel〉. (Accessed 1 Mai 2014).

MME, 2015. Ministério das Minas e Energia. O Programa Nacional de Produção e Uso do Biodiesel. 2015. 〈http://www.mme.gov.br/programas/biodiesel/menu/biodiesel/ pnpb.html $\rangle$. (Accessed 10 December, 2015).

Monke, E.A., Pearson, S.R., 1989. The Policy Analysis Matrix for Agricultural Development. Cornell University Press, Ithaca.

Monstadt, J., Wolff, A., 2015. Energy transition or incremental change? Green policy agendas and the adaptability of the urban energy regime in Los Angeles. Energy Policy 78, 213-224. http://dx.doi.org/10.1016/j.enpol.2014.10.022.
Mulugetta, Y., 2009. Evaluating the economics of biodiesel in Africa. Renew. Sustain. Energy Rev. 13 (6-7), 1592-1598.

Mundaca, L., Neij, L., Markandya, A., Hennicke, P., Yan, J., 2016. Towards a green energy economy? Assessing policy choices, strategies and transitional pathways. Appl. Energy 179, 1283-1292. http://dx.doi.org/10.1016/j.apenergy.2016.08.086.

Murta, A.L.S., 2008. Análise da viabilidade de autoprodução de biodiesel por frotas: o caso da Vale. Tese de doutorado defendida na Coordenação dos Programas de PósGraduação de Engenharia da Universidade Federal do Rio de Janeiro (COPPEUFRJ), 216 p.

Nelson, G.C., Panggabean, M., 1991. The Costs of Indonesian sugar policy: a Policy Analysis Matrix approach. Am. J. Agric. Econ. 73 (3), 703-712.

Newbery, D.M., 2016. Towards a green energy economy? The EU Energy Union's transition to low-carbon zero subsidy electricity system - lessons from the UK's Electricity Market Reform. Appl. Energy 179, 1321-1330. http://dx.doi.org/ 10.1016/j.apenergy.2016.01.046.

Padula, A.D., Santos, M.S., Ferreira, L., Borenstein, D., 2012. The emergence of the biodiesel industry in Brazil: current figures and future prospects. Energy Policy 44, 395-405. http://dx.doi.org/10.1016/j.enpol.2012.02.003.

Pahle, M., Pachauri, S., Steimbacher, K., 2016. Can the Green Economy deliver it all? Experience of renewable energy policies with socio-economic objectives. Appl. Energy 179, 1331-1341. http://dx.doi.org/10.1016/j.apenergy.2016.06.073.

Pearson, S., Gotsch, C., Bahri, S. 2003. Applications of the Policy Analysis Matrix in Indonesian agriculture. Part One: Theoretical concepts and empirical procedures, 116. 〈http://web.stanford.edu/group/FRI/indonesia/newregional/newbook.pdf). (Accessed 10 February 2017).

Pegels, A., Lütkenhorst, W., 2014. Is Germany's energy transition a case of successful green industrial policy? Contrasting wind and solar PV. Energy Policy 74, 522-534. http://dx.doi.org/10.1016/j.enpol.2014.06.031.

Porter, M.E., 1985. Competitive Advantage. Free Press, New York.

Queiroz, A.G., França, L., Ponte, M.X., 2012. The life cycle assessment of biodiesel from palm oil ("dende"”) in the Amazon. Biomass Bioenergy 36, 50-59. http://dx.doi.org/ 10.1016/j.apenergy.2011.11.021.

Rathmann, R., Padula, A.D., 2011. The decision-making process of the agents belonging to the biodiesel production chain in Southern Brazil. J. Agric. Sci. Technol. B1, $865-873$.

Rathmann, R., Szklo, A., Schaeffer, R., 2010. Land use competition for production of food and liquid biofuels: an analysis of the arguments in the current debate. Renew. Energy 35, 14-22. http://dx.doi.org/10.1016/j.renene.2009.02.025.

Rathmann, R., Szklo, A., Schaeffer, R., 2012. Targets and results of the Brazilian Biodiesel Incentive Program - has it reached the promised land? Appl. Energy 97, 91-100. http://dx.doi.org/10.1016/j.apenergy.2011.11.021.

Rincón, L.E., Valencia, M.J., Hernández, V., Matallana, L.G., Cardona, C.A., 2015. Optimization of the Colombian biodiesel supply chain from oil palm crop based on techno-economical and environmental criteria. Energy Econ. 47, 154-167. http:// dx.doi.org/10.1016/j.eneco.2014.10.018.

Ringel, M., Schlomann, B., Krail, M., Rohde, C., 2016. Towards a green economy in Germany? The role of energy efficiency policies. Appl. Energy 179, 1293-1303. http://dx.doi.org/10.1016/j.apenergy.2016.03.063.

Rodrik, D., 2014. Green industrial policy. Oxf. Rev. Econ. Policy 30 (3), 469-491. http:// dx.doi.org/10.1093/oxrep/gru025.

Rodrik, D., 2009. Industrial policy: don't ask why, ask how. Middle East Dev. J. 1 (1), 1-29. http://dx.doi.org/10.1142/S1793812009000024.

Santos, O.I.B., Rathmann, R., 2009. Identification and analysis of local and regional impacts from the introduction of biodiesel production in the state of Piauí. Energy Policy 37, 4011-4029. http://dx.doi.org/10.1016/j.enpol.2009.05.002.

Savi, E.S., Kochhan, L.E., 2016. Produtores estão conhecendo melhor os pontos críticos da cultura. Associação Brasileira de Produtores de Rapeseed (ABRASRAPESEED), 07/06/2016. 〈http://abrasrapeseed.com.br/?Menu=noticias \& id=77〉. (Accessed 6 July 2016).

Schmitz, H., Johnson, O., Altenburg, T., 2013. Rent management-the heart of green industrial policy, IDS Working Paper, No. 418, Institute of Development Studies. 〈http://www.ids.ac.uk/publication/rent-management-the-heart-of-green-industrialpolicy $\rangle$. (Accessed 6 July 2016).

Sergent, A., 2014. Sector-based political analysis of energy transition: green shift in the forest policy regime in France. Energy Policy 73, 491-500. http://dx.doi.org/ 10.1016/j.enpol.2014.06.008.

Shah, K.U., Niles, K., 2016. Energy policy in the Caribbean green economy context and the Institutional Analysis and Design (IAD) framework as a proposed tool for development. Energy Policy 98, 768-777. http://dx.doi.org/10.1016/ j.enpol.2016.07.045.

Silva, P.R.F., Freitas, T.F.S., 2008. Biodiesel: o ônos e o bônus de produzir combustível. Ciência Rural 38 (3), 843-851.

Sorda, G., Banse, M., Kemfert, C., 2010. An overview of biofuel policies across the world. Energy Policy 38, 6977-6988. http://dx.doi.org/10.1016/enpol.2010.06.066.

Souto, K.C., Sicsú, A.B., 2011. A cadeia produtiva da mamona no estado da Paraíba: uma análise pós-programa do biodiesel. Doc. Técnico-Científicos 42 (1), 183-210.

Souza, A.R.L., 2014. Competitividade da cadeia produtiva de arroz beneficiado do Rio Grande do Sul e do Uruguai: um estudo utilizando a matriz de análise de políticas (PAM). Tese (Doutorado) Programa de Pós-Graduação em Agronegócios, Universidade Federal do Rio Grande do Sul Porto Alegre.

Souza, A.R.L., Révillion, J.P.P., Waquil, P.D., Belarmino, L.C., Lanfranco, B.A., 2017. Economic and accounting evaluation of rice milled production chain in Rio Grande do Sul (Brazil) and Uruguay with application of the Policy Analysis Matrix. Ciência Ruaral 47 (04), 1-7. http://dx.doi.org/10.1590/0103-8478cr20151085.

Stattman, S.L., Hospes, O., Mol, A.P.J., 2013. Governing biofuels in Brazil: a comparison of ethanol and biodiesel policies. Energy Policy 61, 22-30. 〈https://doi.org/10. 
1016/j.enpol.2013.06.005>.

Takahashi, F., Ortega, E., 2010. Assessing the sustainability of Brazilian oleaginous crops - possible raw material to produce biodiesel. Energy Policy 38, 2446-2454. 〈https:// doi.org/10.1016/j.jepol.2009.12.038>.

Torres, D.P.A., Lima Filho, J.R., Belarmino, L.C., 2013. Competitividade de cadeias agroindustriais brasileiras. Embrapa, Brasilia - DF, 191.

Ugochukwu, A.I., Ezedinma, C.I., 2011. Intesnsification of rice production systems in southeastern Nigeria: a Policy Analysis Matrix approach. Int. J. Agric. Manag. Dev. 1 (2), 89-100.

Ürge-Vorsatz, D., et al., 2016. Measuring multiple impacts of low-carbon energy options in a green economy context. Appl. Energy 179, 1409-1426. http://dx.doi.org/ 10.1016/j.apenergy.2016.07.027.

USDA, 2012. United States Department of Agriculture. USDA Agricultural Projections to 2021. p.102. Washington - DC. 〈http://www.usda.gov/oce/commodity/archive projections/USDAAgriculturalProjections2021.pdf $\rangle$. (Accessed 9 September 2015).

USDA, 2015. United States Department of Agriculture. Brazil. Biofuels Annual. Biofuels Ethanol and Biodiesel. GAIN Report Number BR15006. 〈http://gain.fas.usda.gov/ RecentGAINPublications/BiofuelsAnnual_SaoPauloATO_Brazil_8-4-2015.pdf). (Accessed 1 April 2016).

Vaccaro, G.L.R., Pohlmann, C., Cirne Lima, A., Santos, M.S., Souza, C.B., Azevedo, D., 2010. Prospective scenarios for for the biodiesel chain of a Brazilian state. Renew. Sustain. Energy Rev. 14, 1263-1272. http://dx.doi.org/10.1016/j.rser.2009.12.008.

Vaz, P.H.P.M., Sampaio, Y.S.B., Sampaio, E.V.S.B., 2010. Análise da competitividade da mamona e da soja para a produção de biodiesel no nordeste do Brasil. Rev. Econ. Agríc. 57 (1), 35-48.

Viegas, A., 2014. Produção de biodiesel em MS cresce percentualmente acima do país. /http://g1.globo.com/mato-grosso/agrodebate/noticia/2014/09/producao-de- biodiesel-em-ms-cresce-percentualmente-acima-do-pais.html) $\rangle$. (Accessed 9 September 2015).

Vieira, L.C., 1996. Utilização da policy analysis Matriz na avaliação e elaboração de políticas públicas para a agricultura. Agric. São Paulo 43 (1), 137-154.

Vieira, R.C.M., Lima Filho, J.R.T., Oliveira, A.J., Lopes, M.R., 2001. Cadeias produtivas no Brasil: análise da competitividade. Embrapa, Brasília - DF, 469p.

Vochozka, M., Marousková, A., 2017. Implications of the EU green energy policy on financial performance of crop production and water management of topsoil. Clean. Technol. Environ. Policy 19, 603-609. http://dx.doi.org/10.1007/s10098-0161256-2.

Wang, C., Zhang, W., Cai, W., Xie, X., 2013. Employment impacts of CDM projects in China's power sector. Energy Policy 59, 481-491. http://dx.doi.org/10.1016/ j.enpol.2013.04.010.

Wang, S.L., Heisey, P., Schimmelpfenning, D., Bali, E., 2015. Agricultural productivity growth in the United States: measurement, trends, and drivers. Wasingthon-DC, Economic Research Report-189 - ERS-USDA, 78 p.

Watanabe, K., Zylbersztajn, D., 2012. Building supply systems from scratch: the case of the castor bean biodiesel chain in Minas Gerais, Brazil. Int. J. Food Syst. Dyn. 3 (2), $185-198$.

White, W., Lunnan, A., Nybakk, E., Kulisic, B., 2013. The role of governments in renewable energy: the importance of policy consistency. Biomass Bioenergy 57, 97-105. http://dx.doi.org/10.1016/j.biombioe.2012.12.035.

Williams, D., 2010. Industrial Policy. Local Econ. 25 (8), 612-621. http://dx.doi.org/ 10.1080/02690942.2010.533425.

Zonin, V.J., Antunes, J.A.V., Jr, Leis, R.P., 2014. Multicriteria analysis of agricultural raw materials: a case study of BSBIOS and PETROBRAS BIOFUELS in Brazil. Energy Policy 67, 255-263. http://dx.doi.org/10.1016/j.enpol.2013.12.029. 